\title{
Activity and distribution of attached bacteria in Chesapeake Bay*
}

\author{
Peter Griffith ${ }^{1, * *}$, Fuh-Kwo Shiah ${ }^{2}$, Kathryn Gloersen ${ }^{2}$, Hugh W. Ducklow ${ }^{2}$, \\ Madilyn Fletcher ${ }^{1}$ \\ ${ }^{1}$ Center of Marine Biotechnology, Maryland Biotechnology Institute, University of Maryland System, 600 East Lombard St., \\ Baltimore, Maryland 21202, USA \\ ${ }^{2}$ Horn Point Environmental Laboratory, Center for Environmental Estuarine Studies, University of Maryland System, \\ Cambridge, Maryland 21613, USA
}

\begin{abstract}
The purpose of this study was to further our understanding of the role of particle-associated bacteria in phytoplankton degradation in the Chesapeake Bay, USA, and to identify environmental parameters that control production by free and particle-associated bacteria. Surface and bottom waters at 10 stations along the length of the Bay were sampled over a 2 yr period. Samples were analyzed for temperature, salinity, chlorophyll, phaeophytin, particulate protein, thymidine incorporation (an estimate of bacterial growth rate), and bacterial total direct counts. Results demonstrated that freeliving bacteria were responsible for most of the total bacterial production, which was correlated with temperature and particulate protein, but not with chlorophyll. In contrast, attached bacteria were much more active than free-living bacteria on a per-cell basis. Cell-specific thymidine incorporation by freeliving bacteria correlated with temperature and particulate protein quantity, whereas that by attached bacteria correlated with temperature, particulate protein quantity and particulate organic quality, as indicated by extent of phytoplankton degradation
\end{abstract}

KEY WORDS: Bacteria - Detritus · Chesapeake Bay

\section{INTRODUCTION}

The Chesapeake Bay, USA, is a eutrophic estuary with an abundant and active bacterial community. Bacterial processes have been extensively studied in the middle portion of the Chesapeake Bay (Jonas 1992, Ducklow \& Shiah 1993), where they are implicated in the creation of an anoxic zone in deeper waters during the summer months. High levels of primary production result in accumulations of phytoplankton, and subsequently phytodetritus, which sink in the water column and are not fully degraded before settling at the bottom. The factors that limit degradation of such particulate material are not fully under-

\footnotetext{
- Contribution No. 224 of the Center of Marine Biotechnology

- Present address: North American Collection and Location by Satellite, 9200 Basil Court, Suite 306, Landover, Maryland 20785, USA
}

stood. It is generally assumed that in aquatic environments phytodetritus is degraded primarily by bacteria attached to the particulate material (Hoppe 1991). However, free-swimming bacteria may be able to graze on particulate substrates without becoming firmly attached (Kefford et al. 1982).

Few studies in the Chesapeake Bay have investigated the role of attached bacteria in the breakdown of particulate phytodetritus. Since typically more than half of phytoplankton productivity is in the form of particulate, rather than dissolved, organic matter (Baines \& Pace 1991), we hypothesized that attached bacteria play a significant role in the breakdown of particulate matter. Moreover, laboratory studies indicated that particle-associated substrate was hydrolyzed by attached bacteria (Griffith \& Fletcher 1990, 1991). Thus, we compared the abundance and production of both free bacteria and those associated with particles in surface and bottom waters along the length of Chesapeake Bay. These bacterial parameters were analyzed 
with respect to parameters related to phytoplankton abundance and quality, i.e. chlorophyll, particulate protein, phaeophytin/chlorophyll ratio, as well as to temperature. Our primary aim was to evaluate the extent to which phytodetritus degradation is carried out by attached bacteria.

We determined the following at a series of sampling stations in the upper, middle, and lower Chesapeake Bay during 1990 and 1991: (1) the numbers and production of attached bacteria; (2) the abundance and production of attached bacteria relative to free-living bacteria; and (3) correlations of numbers and per-liter and per-cell production of free-living and attached bacteria with temperature, chlorophyll, particulate substrate quantity (protein) and particulate substrate

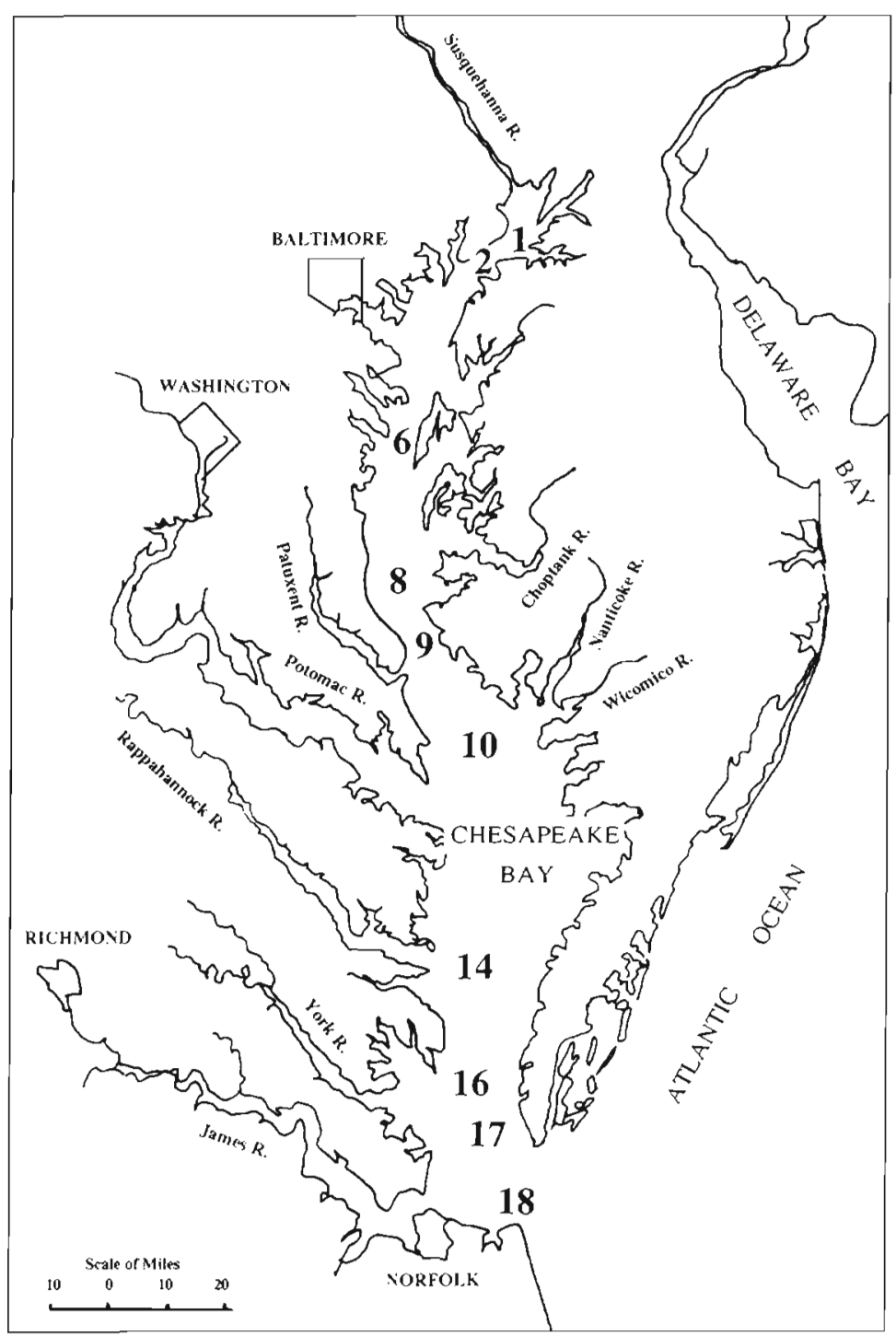

Fig. 1. Chesapeake Bay, USA, showing location of sampling stations designated by the LMER study program quality (phaeophytin/chlorophyll ratio). We hypothesized that attached bacteria would be an important part of the bacterial community.

\section{MATERIALS AND METHODS}

During 1990 and 1991 we repeatedly sampled surface and bottom waters at 10 stations (Fig. 1), which were also monitored by researchers with the Land Margin Ecosystem Research (LMER) program. At each station, a hydrocast sample was taken by CTD rosette approximately $1 \mathrm{~m}$ above the bottom and $1 \mathrm{~m}$ below the surface. Sampling stations were located in the upper (Stns 1 and 2), middle (8, 9 and 10), and lower $(16,17$ and 18) regions of the Bay (Table 1). Samples were also taken at 2 intermediate stations, one between the upper and middle Bay (Stn 6) and the other between the middle and lower Bay (Stn 14). Samples were analyzed for temperature, salinity, chlorophyll, phaeophytin, particulate protein, thymidine incorporation (an estimate of bacterial growth rate) and bacterial cell counts

For determination of protein content in particulate material, particles were collected by filtration of 200 to $600 \mathrm{ml}$ of sample water through $25 \mathrm{~mm}$ diameter GF/F glass fiber filters. After filtration, filters were immediately frozen on dry ice and stored at $-20^{\circ} \mathrm{C}$ until analysis. Protein was extracted from particulate material retained on each filter by placing the filter in $1 \mathrm{ml}$ sodium dodecyl sulfate (SDS, $1 \%$ ) in a microcentrifuge tube. Tubes were sonicated in an ultrasonic water bath (Cole-Parmer 8851) for $1 \mathrm{~h}$, vortexed for $1 \mathrm{~min}$ to mix sample, and centrifuged in a microfuge at $9880 \times g(11000 \mathrm{rpm})$ for $5 \mathrm{~min}$ to pellet undissolved material. Protein content of SDS-soluble extract was estimated in triplicate using the BCA Protein Assay Reagent (Pierce, Rockford, IL, USA). Bovine serum albumin (BSA) was employed as a standard.

Estimates of temperature, salinity, chlorophyll and phaeophytin were obtained using methods described in detail elsewhere (Malone et al. 1986, Malone \& Ducklow 1990) and kindly provided to us by the LMER program.

Free-living and attached bacteria were differentiated operationally using $3 \mu \mathrm{m}$ Nuclepore filters (Kirchman \& Mitchell, 1982). Samples $(10$ to $30 \mathrm{ml})$ were filtered through $3 \mu \mathrm{m}$ filters to estimate abundance of particles and attached bacteria present at 
Table 1. Characteristics of sampling stations in Chesapeake Bay, USA

\begin{tabular}{|lcccc|}
\hline Region & Stn & $\begin{array}{c}\text { Depth } \\
(\mathrm{m})\end{array}$ & $\begin{array}{c}\text { Salinity } \\
(\mathrm{ppt})\end{array}$ & $\begin{array}{c}\text { Summer } \\
\text { anoxia? }\end{array}$ \\
\hline Upper Bay & 1,2 & 5 & $0.1-9$ & No \\
Middle Bay & $8,9,10$ & 30 & $10-20$ & Yes \\
Lower Bay & $16,17,18$ & 30 & $20-32$ & No \\
\hline
\end{tabular}

low concentration. Samples ( $1 \mathrm{mI}$ and $10 \mathrm{ml}$ ) were filtered onto $0.2 \mu \mathrm{m}$ Nuclepore filters for the estimation of total abundance and production, respectively. Cells were enumerated using acridine orange direct counts (Hobbie et al. 1977) on a Zeiss Axiophot microscope with a $100 \mathrm{~W}$ mercury lamp and the $60 \times$ objective.

Attached cell abundance was estimated by counting all cells in contact with particles on the $3 \mu \mathrm{m}$ filters. This simple procedure neglects the attached cells hidden on the undersides of particles, and those free cells which settle onto particles during filtration. Thus, our estimates may be either under- or overestimates, depending on the relative importance of these 2 artefacts, and the degree of particle colonization. Clarke \& Joint (1986), using a rigorous procedure for addressing these effects, showed that both types of artefact result in low errors when the particle concentration is low, as is the case in all areas of the Chesapeake Bay.

Bacterial production was estimated by measuring the rate of [methyl- ${ }^{3} \mathrm{H}$ ] thymidine incorporation by bacterial samples (Fuhrman \& Azam 1980, 1982). Samples $(60 \mathrm{ml})$ of freshly collected water were incubated with [methy]- ${ }^{3} \mathrm{H}$ ] thymidine (specific activity 20 to $85 \mathrm{Ci}$ $\mathrm{mmol}^{-1}$, final concentration $5 \mathrm{nM}$ ) in the dark in polycarbonate bottles at in situ temperatures from $30 \mathrm{~min}$ to $1 \mathrm{~h}$. Longer incubation times were used when in situ temperatures were lower. Preliminary tests showed that this concentration saturated thymidine uptake systems of natural heterotrophic bacterioplankton from these sampling areas (data not shown). The reaction was stopped by adding formaldehyde (final concentration $1 \%$ ). This was done to eliminate incorporation of label during the filtration step, which could be a large fraction of the incubation time for turbid samples with high activity. Formalin treatment did not appear to result in cross-linking of macromolecules and did not increase the TCA-insoluble or phenol-chloroformextractable fraction of label incorporated (Ducklow unpubl. data, T. Hollibaugh pers. comm.).

Thymidine incorporation by attached cells was defined as the label retained on the $3 \mu \mathrm{m}$ filters after filtration, TCA extraction, and ethanol rinsing. Incorporation by free-living cells was calculated as the difference between the radioactivity on the 0.2 and $3 \mu \mathrm{m}$ filters. This procedure may overestimate the incorpora- tion by attached cells by counting radioactivity in freeliving cells retained on the $3 \mu \mathrm{m}$ filter. Microscopic examination showed that this effect was usually minor, except on sporadic occasions in the stratified bottom layer of the middle Bay in summer when large filamentous bacteria increased in abundance.

Killed samples were filtered through $0.2 \mu \mathrm{m}(2 \times$ $10 \mathrm{ml})$ and $3.0 \mu \mathrm{m}(2 \times 20 \mathrm{ml})$ polycarbonate filters and rinsed 4 times each with ice-cold 5\% TCA and $80 \%$ ethyl alcohol. Ten $\mathrm{ml}$ of scintillation cocktail (Formula 963, Dupont) was added after filters were put into vials and dried overnight at $35^{\circ} \mathrm{C}$. Radioactivity in vials was determined by liquid scintillation counting (2200CA, Packard) at the Horn Point Laboratory, University of Maryland.

Statistical analysis was performed using SuperANOVA (version 1.11). Simple and multiple regressions were performed with Type III sums of squares, which were designed to remove the effect of all of the other effects in the model, before testing the effect in question (Abacus Concepts 1989).

\section{RESULTS}

\section{Chlorophyll}

In surface and bottom waters of the upper Bay, chlorophyll increased between February and May, when it reached its maximum value. Chlorophyll remained relatively stable at around 5 to $10 \mu \mathrm{g} \mathrm{I}^{-1}$ for the remainder of the year (Fig, 2A, D). Maximum chlorophyll in the upper Bay was about half that observed in the middle Bay. The highest chlorophyll levels in the Bay were found in the middle Bay during April in surface waters, and in February, March and April in bottom waters (Fig. 2B, E). Chlorophyll decreased somewhat in mid-Bay surface waters in May. In bottom waters, chlorophyll values were very low during June through September, when these waters were anoxic. Chlorophyll increased in bottom waters in October, when autumn storms begin to break up the anoxic zone.

In the lower Bay, chlorophyll ranged from 3 to $14 \mu \mathrm{g}$ $1^{-1}$, with maximum levels observed in April, August and November (Fig. 2C, F). Maximum chlorophyll in the lower Bay was about half that observed in the middle Bay.

\section{Particulate protein}

Particulate protein was positively correlated with chlorophyll $\left(\mathrm{r}^{2}=0.72, \mathrm{p}<0.01\right)$ (Fig. 3). Chlorophyll represented $2.3 \% \pm 0.2 \%(\mathrm{SE}, \mathrm{n}=143)$ of total particu- 
Surface
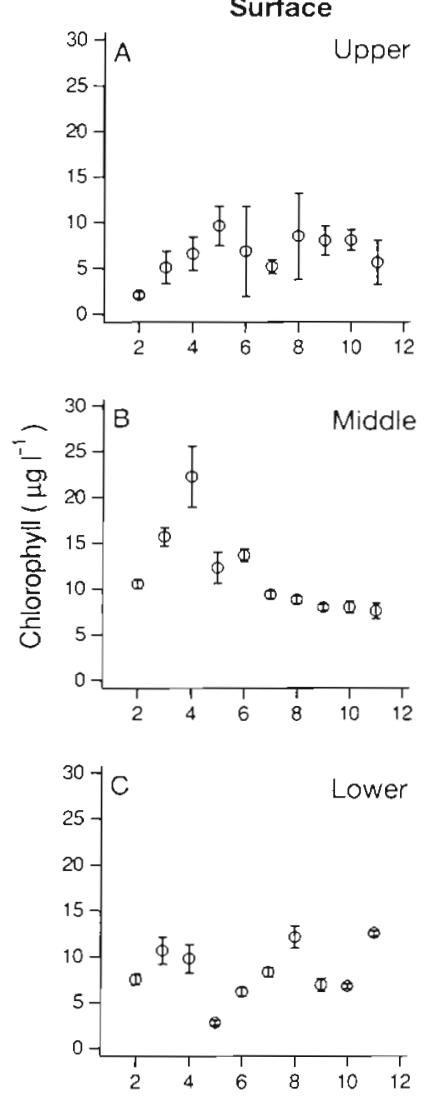

Bottom

Upper
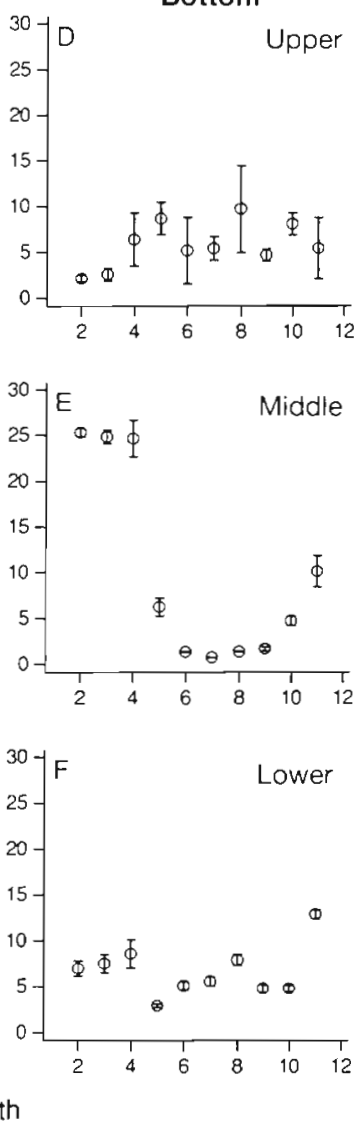

Fig. 2. Chlorophyll in surface $(A, B, C)$ and bottom $(D, E, F)$ waters in the upper $(A, D)$, middle $(B, E)$ and lower $(C, F)$ Chesapeake Bay. Each point represents the average $( \pm \mathrm{SE})$ for a given month in 1990 and 1991 at stations within that Bay region (Table 1 )

late protein on a per-gram basis. Particulate protein and phaeophytin were not as strongly correlated $\left(r^{2}=\right.$ $0.4167, p<0.01)$.

\section{Bacterial numbers}

Attached bacteria were most numerous in the upper Bay (Fig. 4A, D) and in the surface waters of the middle Bay (Fig. 4B). In these locations, attached bacteria were at their lowest values in November, but the rest of the year exhibited no clear seasonality. Low numbers of attached bacteria occurred in bottom waters of the middle Bay from April to June, followed by increased numbers beginning in August. In the lower Bay, no seasonal trends in attached bacterial numbers were observed in surface or bottom waters. Attached bacteria numbers generally were $<10 \%$ of total bacterial numbers (Fig. 5), except in the upper Bay, where attached bacteria represented 5 to $30 \%$ of the bacterial community.

\section{Bacterial thymidine incorporation}

Thymidine incorporation by attached bacteria on a per-liter basis was generally highest in the surface and bottom waters of the upper Bay (Fig. 6A, D), and in the surface waters of the middle Bay in summer (Fig. 6B). Small summer increases in thymidine incorporation were observed in surface and bottom waters of the lower Bay (Fig. 6C, F). Attached bacteria were usually responsible for 5 to $10 \%$ of the total bacterial thymidine incorporation (Fig. 7), except in the upper Bay from February to April, where attached bacteria accounted for 25 to $50 \%$ of total bacterial thymidine incorporation (Fig. 7 A, D), and in the bottom waters of the middle Bay in February and March, where they accounted for approximately $25 \%$ of bacterial activity (Fig. 7E).

\section{Cell-specific bacterial thymidine incorporation}

Throughout the Bay, cell-specific thymidine incorporation by attached bacteria was at a minimum from September through February, somewhat higher during

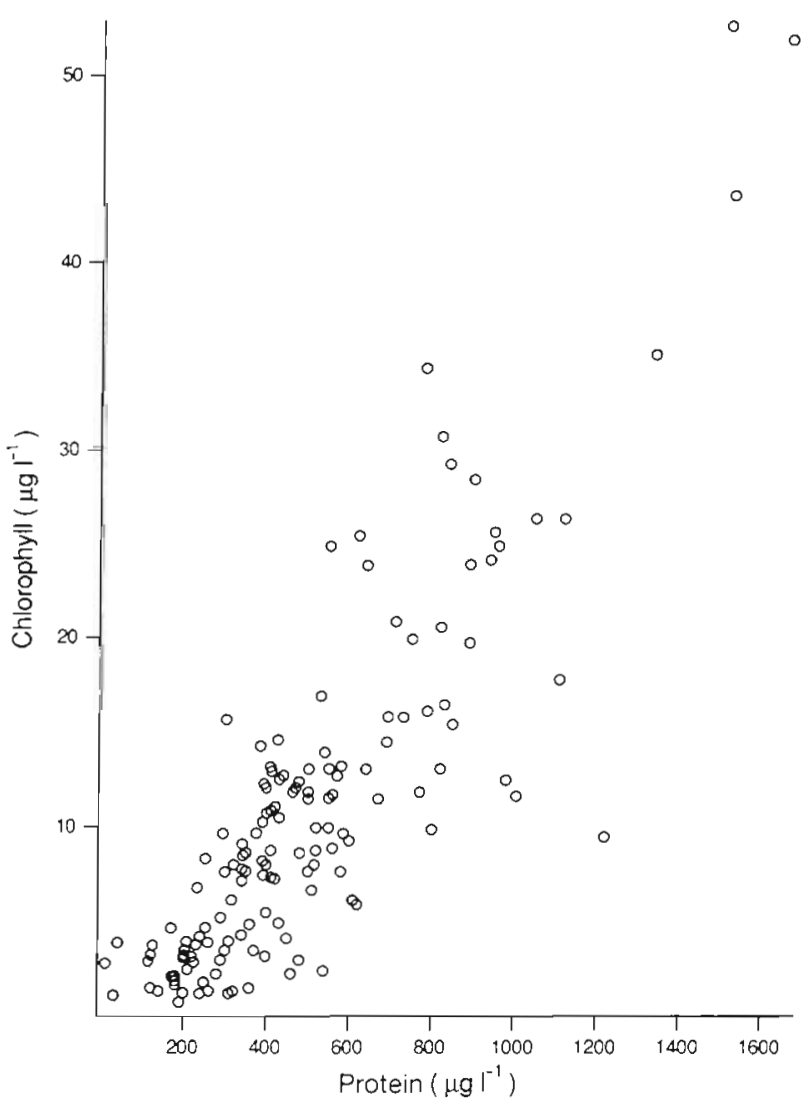

Fig. 3. Relationshup between particulate protein and chlorophyll from all stations $\left(r^{2}=0.7212, p<0.01\right)$ 
Surface
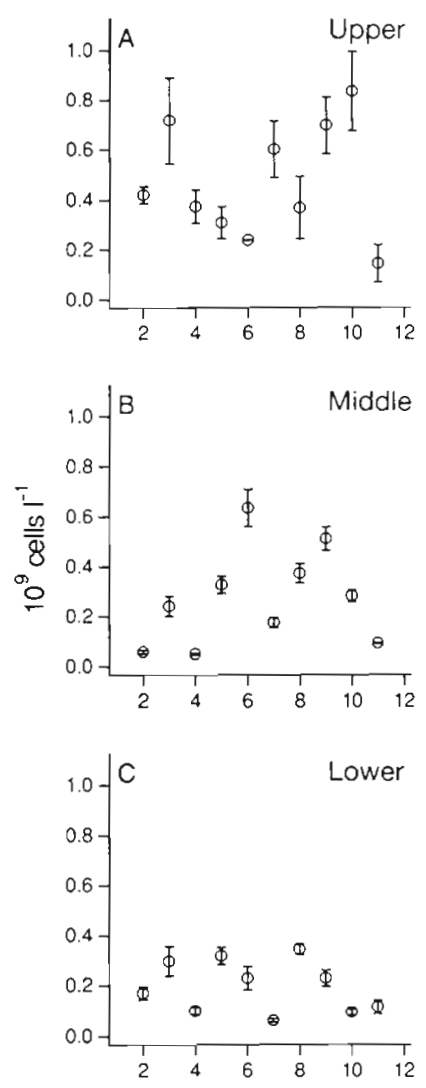

Bottom
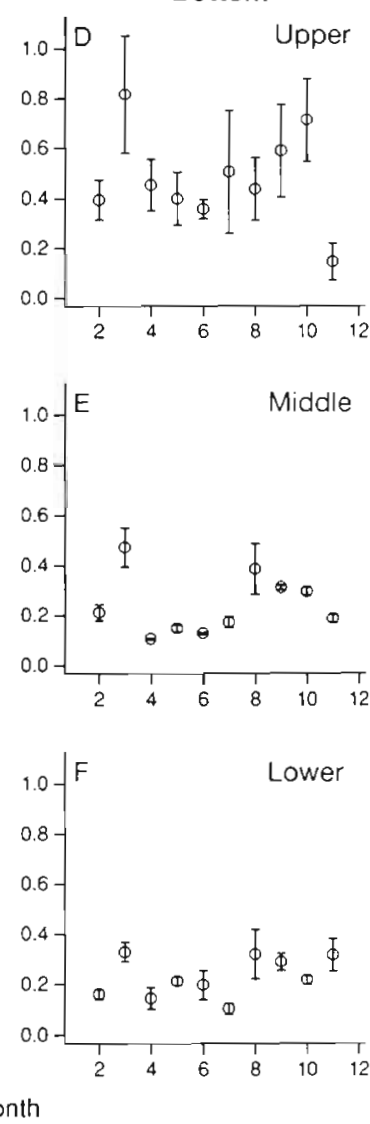

Fig. 4. Number $( \pm \mathrm{SE}$ ) of attached bacteria per liter of water from specific regions in the Chesapeake Bay. Each point represents the average for all stations within a region for a given month in 1990 and 1991

the other months, particularly in May, when cellspecific metabolism rose in the upper Bay (Fig. 8A, D), and in July, when there was a Bay-wide maximum in thymidine incorporation by attached bacteria on a percell basis (Fig. 8). Cell-specific thymidine incorporation by attached bacteria was 2 to 15 times greater than that of free-living bacteria (Fig. 9), but showed no clear seasonal trends.

\section{Correlations with bacterial metabolism}

Simple regressions were performed to assess the relationship between bacterial parameters and the effects of temperature, particulate protein, chlorophyll and phaeophytin/chlorophyll (Table 2). Free-living bacterial numbers were correlated only with temperature. Per-liter incorporation of thymidine was correlated with temperature and protein concentration, but not chlorophyll or phaeophytin/chlorophyll. Per-cell

incorporation of thymidine was correlated only with temperature.

Correlations with attached bacteria were somewhat different. Their numbers were correlated with temperature and phaeophytin/chlorophyll. The per-liter thymidine incorporation of attached bacteria was correlated with temperature, particulate protein and chlorophyll. Thymidine incorporation per attached cell was correlated with temperature, particulate protein chlorophyll and phaeophytin/chlorophyll. All significant correlations were positive, except for the correlation between thymidine incorporation per attached cell and phaeophytin/chlorophyll.

None of the simple regressions explained more than $51 \%$ of the variance in bacterial parameters (Table 2 ). The combined effects of temperature and particulate protein were better predictors of bacterial parameters (Table 3), including per-liter thymidine incorporation of free and attached bacteria, numbers of free bacteria, and thymidine incorporation per free cell. Only $25 \%$ of the variance in thymidine incorporation per attached
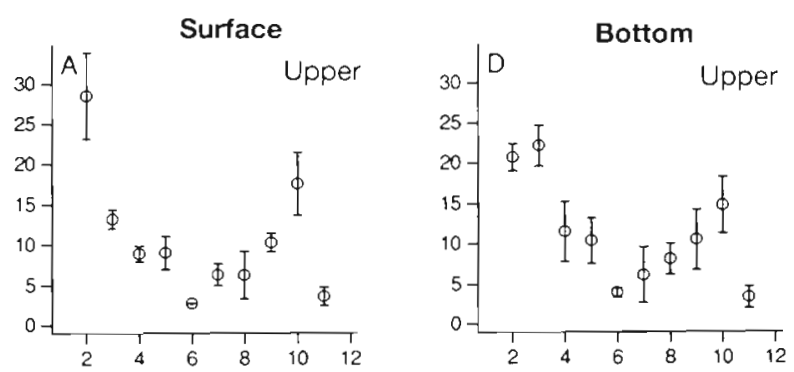

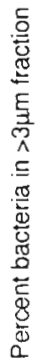
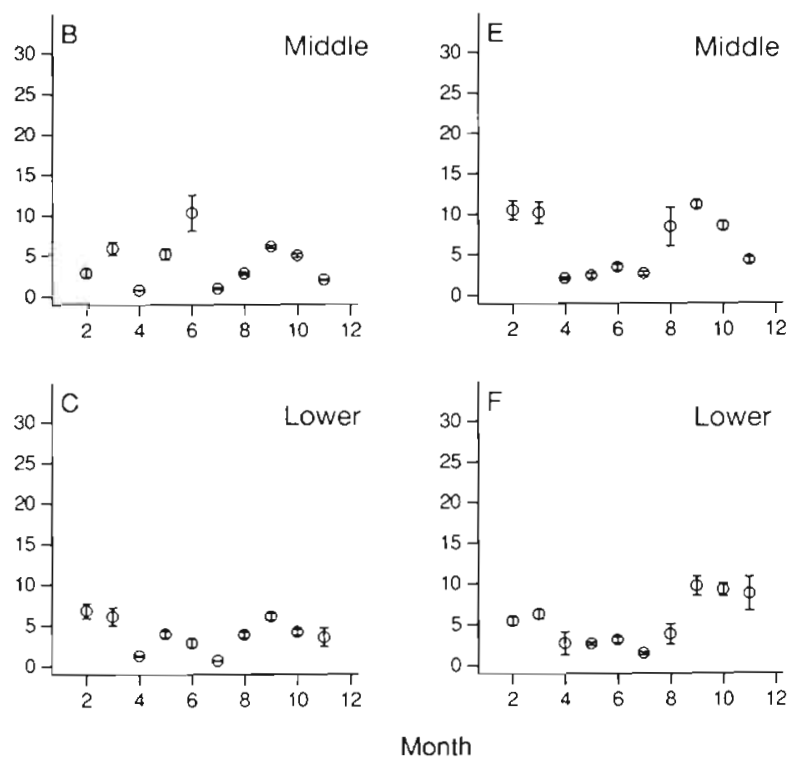

Fig. 5. Number of attached bacteria expressed as a percentage ( $\pm S E$ ) of the total number of bacteria. Each point represents the average for all stations within a region for a given month in 1990 and 1991 
Surface
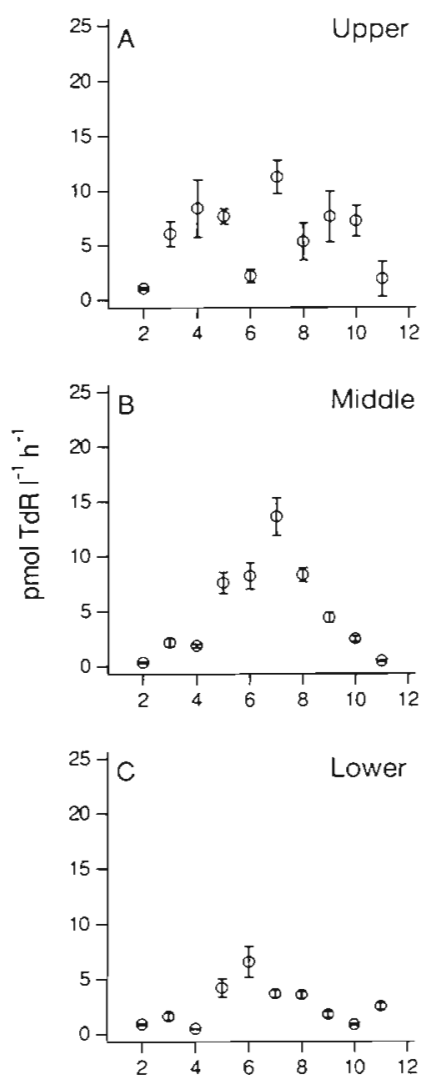

Bottom
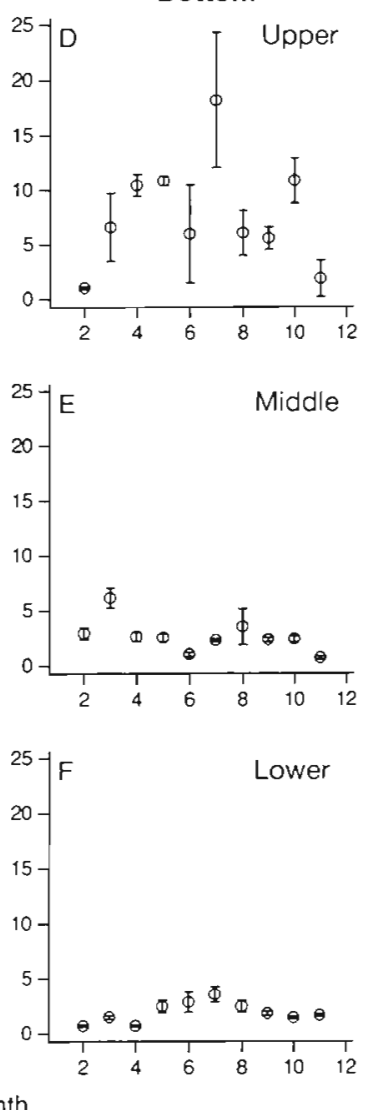

Fig 6. Rate ( $\pm \mathrm{SE}$ ) of thymidine incorporation (TdR) per liter by attached bacteria. Each point represents the average for all stations within a region for a given month in 1990 and 1991

cell was explained by the combined effects of temperature and protein. Addition of the effects of chlorophyll or phaeophytin/chlorophyll did not significantly improve the prediction of bacterial parameters (not shown).

\section{DISCUSSION}

Like physical, chemical and other biological properties, bacterial biomass and production vary in Chesapeake Bay on scales ranging from diel to interannual (Ducklow \& Shiah 1993). In this work we focused on seasonal patterns in 3 sections of the Bay. By combining observations made over 2 calendar years, and combining stations into 3 groups (upper, middle and lower Bay), we have obscured some of the finer-scale spatial and also interannual variations. Our analyses are probably also sensitive to daily variations, because most 'monthly' samples are from a single day each year. Seasonal patterns are nonetheless apparent in surface

and bottom waters in some regions of the Bay. For example, the spring phytoplankton bloom (Malone et al.1988) is clear in the mid-Bay surface and bottom waters (Fig. 2B, E) but not in the upper or lower Bay This is the typical pattern of seasonal chlorophyll variability in the Bay, showing a March-April bloom followed by low biomass in summer.

By 'seasonal pattern' we refer to a clear temporal pattern of rising and declining value of some property, which exhibits similarity to some other known pattern in Bay waters, e.g. the spring phytoplankton bloom or the seasonal cycles of freshwater flow, temperature or oxygen (Malone et al. 1988, Ducklow \& Shiah 1993). Seasonal patterns characterized by bell-shaped curves with summer maxima and winter minima suggest temperature as a principal controlling factor. However primary production is also highest in summer, offset from the springtime chlorophyll peak (Malone et al. 1988). Therefore, distinguishing between temperature and substrate supply as controlling factors for bacteria is not straightforward. Patterns with springtime maxima
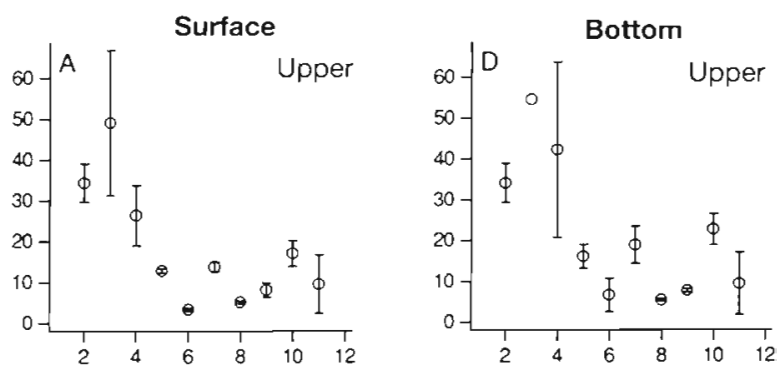

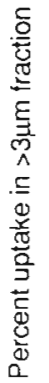
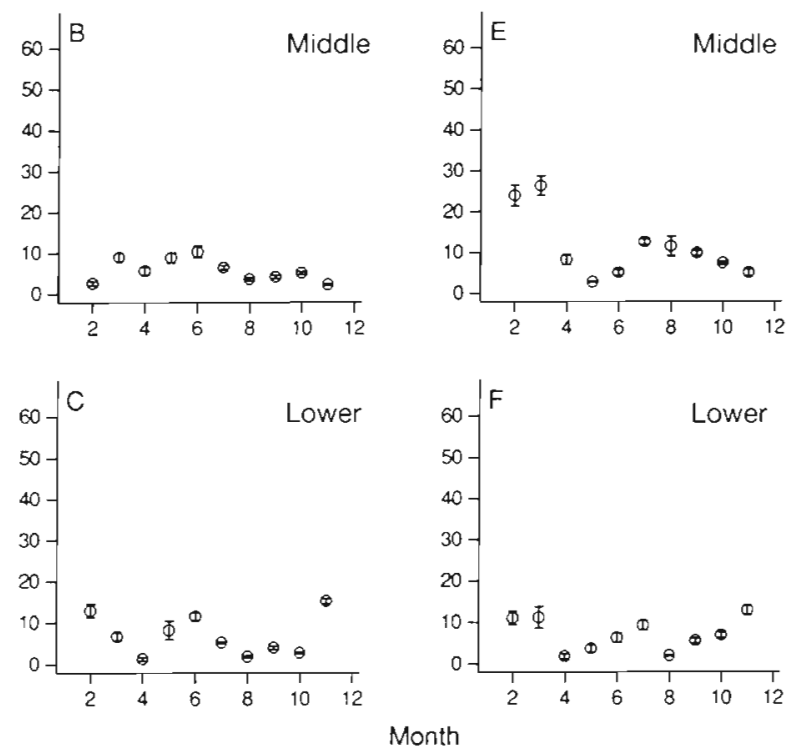

Fig. 7. Thymidine incorporation by attached bacteria expressed as a percentage $( \pm \mathrm{SE}$ ) of total thymidine incorporation. Each point represents the average for all the stations within a region for a given month in 1990 and 1991 

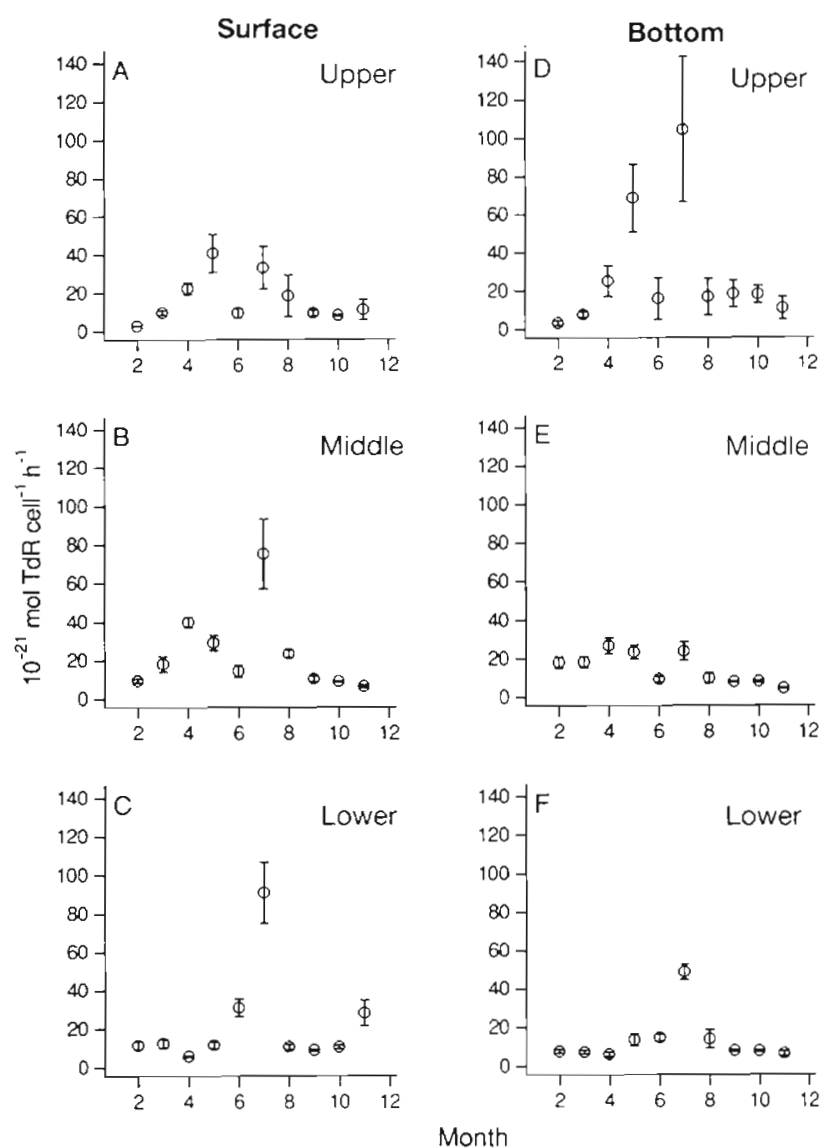

Fig. 8. Rate $( \pm \mathrm{SE})$ of cell-specific thymidine incorporation by attached bacteria. Each point represents the average for all the stations within a region for a given month in 1990 and 1991

might indicate responses to nutrients supplied by freshwater runoff or the phytoplankton bloom. In the former case, bacterial abundance might be inversely correlated with salinity, and in the latter, directly correlated with chlorophyll. In order to sort out some of these effects we also present 1 - and 2 -factor regression analysis of measured properties.

Attached bacterial abundance and production showed a clear pattern of summer maximum/winter minimum in the mid-Bay surface waters (Figs. $4 \mathrm{~B}$ \& $6 \mathrm{~B})$, but this was not evident in the bottom waters (Figs. 4E \& 6E). This is because bacterial activity is depressed in summer in this area by the development of the anoxic bottom layer (Malone et al. 1986, Ducklow \& Shiah 1993). In spite of the depression in bacterial activity, there were measurable rates of thymidine incorporation in anoxic waters. Attached bacterial production showed the same summer maximum/winter minimum pattern with less amplitude in the lower Bay (Fig. 6C, F), and with greater variability in the upper Bay (Fig. 6A, D). Thus, there were similar patterns of attached bacterial abundance in 3 regions of the Bay with distinctly different environmental characteristics: the lower Bay, which is similar to, and under strong influence of the coastal ocean; the middle Bay, a high productivity, mesohaline region with seasonal anoxia; and the upper Bay, a low salinity area, influenced by seasonal patterns of freshwater input. For this reason, and because the patterns survived the averaging treatment we used, the seasonal pattern observed is probably a robust phenomenon controlled primarily by a single factor. This pattern was also somewhat apparent in several regions for attached cell-specific thymidine incorporation, a property reflecting population turnover rates (Fig. 8). No other clear patterns were apparent in our data set.

Attached bacterial variability was greatest and yearly mean values were highest in the upper Bay. This region is characterized by shallow depth, low salinity and chlorophyll, and high particle loads (Fisher et al. 1988). Attached bacteria in the upper Bay might be terrestrial bacteria sorbed onto riverine clay parti-
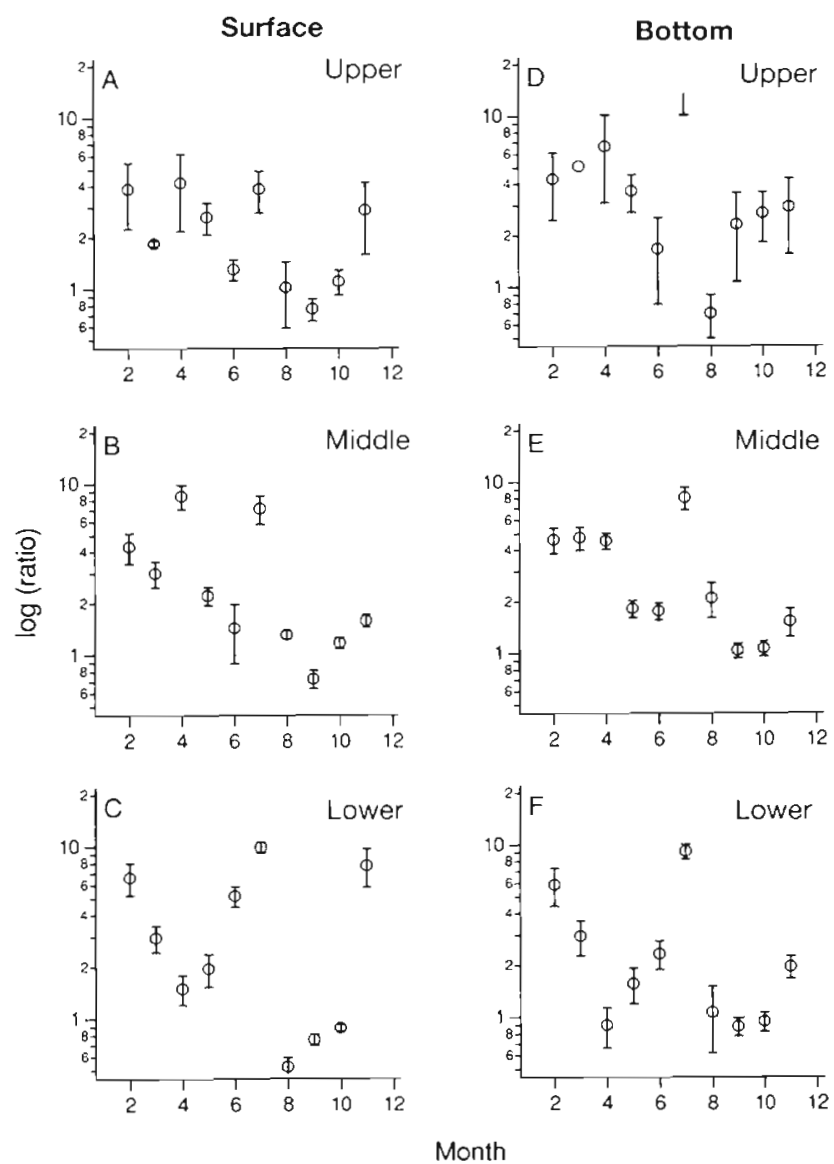

Fig. 9. Ratio $( \pm \mathrm{SE})$ of the cell-specific thymidine incorporation of attached bacteria to that of free-living bacteria. Each point represents the average for all the stations within a region for a given month in 1990 and 1991 
Table 2. Percent of the variance in bacterial numbers and rates of thymidine incorporation on a per-liter and per-cell basis explained in simple regressions with single effects (temperature, protein, chlorophyll and phaeophytin/chlorophyll). Percentages shown are significant at $\mathrm{p}<0.01$. Dependent variables are numbers of bacteria per liter, rate of thymidine incorporation (TdR) per liter and per cell. All variables were log-transformed with the exception of the phaeophytin/chlorophyll ratio, which was arcsine (y) transformed. Transformations were performed after examination of residuals indicated that variances were not normally distributed, in accordance with standard statistical practice (Sokal \& Rohlf 1969, Abacus Concepts 1989). ns: not significant

\begin{tabular}{|c|c|c|c|c|c|c|}
\hline \multirow{2}{*}{ Variable } & \multicolumn{3}{|c|}{ Free } & \multicolumn{3}{|c|}{ Attached } \\
\hline & Numbers & Per-liter Tdr & Per-cell Tdr & Numbers & Per-liter Tdr & Per-cell TdR \\
\hline Temperature & 24 & 51 & 37 & 4 & 16 & 5 \\
\hline Protein & ns & 6 & ns & ns & 11 & 20 \\
\hline Chlorophyll & ns & ns & ns & ns & 6 & 8 \\
\hline Phae/chl & ns & ns & ns & 7 & ns & 4 \\
\hline
\end{tabular}

cles, and may be dying as they encounter increased salinities in transit (Painchaud et al. 1987). The lack of any clear pattern might be a consequence of shorterterm variability in sediment transport and resuspension in the upper Bay.

Temperature has been recognized as a very important physical factor affecting heterotrophic bacterioplankton (HBP) substrate uptake activity (Iriberri et al. 1985, Pomeroy \& Deibel 1986, Pomeroy et al. 1991), abundance and production (Lovell \& Konopka 1985. Coffin \& Sharp 1987, Findlay et al. 1991, White et al. 1991). The patterns observed in this study suggest that temperature is a primary factor regulating bacterial abundance and production in the Bay. Ducklow \& Shiah (1993) analyzed a large data set on total bacterial abundance and thymidine incorporation in the middle Bay collected between 1984 and 1989 and found significant regressions only with temperature. The low coefficient of determination they found (38\%) was probably due to competing effects of interannual and shorter-term variations in salinity, oxygen and primary production. However, short-term assays of thymidine incorporation in samples incubated at a range of temperatures above and below ambient also showed a

Table 3. Percent of the variance in bacterial numbers and rates of thymidine incorporation (TdR) on a per-liter and per-cell basis as explained by the combination of temperature and particulate protein in multiple regression $(p<0.01)$. All variables were transformed as in Table 2 . ns: not significant.

\begin{tabular}{|cc|}
\hline & \% variance \\
\hline Free-living & \\
Numbers & 44 \\
TdR I $^{-1}$ & 70 \\
TdR cell $^{-1}$ & 44 \\
Attached & \\
Numbers & ns \\
TdR I $^{-1}$ & 44 \\
TdR cell $^{-1}$ & 25 \\
\hline
\end{tabular}

strong and significant temperature effect during all seasons (F.-K. Shiah unpubl. data). Significant relationships with chlorophyll were not found. Based on these findings, Ducklow \& Shiah (1993) suggested that the response of bacteria to temperature in all seasons indicates a lack of significant substrate limitation in Bay waters. The reasoning behind this hypothesis is that bacteria could not respond to temperature increases in short-term assays unless substrate supply was sufficient to support the increased production.

It is at first surprising that we did not find significant relationships between chlorophyll and most bacterial parameters. Correlations between bacteria and chlorophyll are common properties of many habitats (Cole et al. 1988, Ducklow \& Carlson 1992). However, we did establish significant though very weak relationships for chlorophyll and protein with attached bacterial production and growth rates (Table 2). Furthermore, and more importantly, addition of protein data to the regression analyses improved the temperature regressions from $16 \%$ to $44 \%$ and from $5 \%$ to $25 \%$ for total and per-cell incorporation by attached bacteria respectively. Temperature regressions for free bacteria were also improved by consideration of protein data (from $51 \%$ to $70 \%$ for total thymidine incorporation, and from $37 \%$ to $44 \%$ for per-cell incorporation), but not by as large relative amounts. This suggests that attached bacteria in Chesapeake Bay may experience a greater degree of substrate limitation than free bacteria. We caution, however, that we have not measured any property which indicates free bacterial substrate (i.e. dissolved organic compounds) availability or supply (cf. Ducklow 1992). Our conclusions about the relative lack of substrate control for free bacteria are based solely on the temperature relationships. Our data on attached bacteria suggest the dual control of bacterial growth by substrate (protein) supply and temperature which has been shown in other (mostly cold) regions by Pomeroy \& Deibel (1986) and Wiebe et al. (1992).

Attached bacteria (per liter) were relatively significant in the upper Bay, where turbidity is highest, 
and during the colder months (Figs. $5 \& 7$ ). Attached bacteria had substantially higher rates of thymidine incorporation per cell than did free-living bacteria (Fig. 9). Furthermore, attached bacteria appeared to be less influenced by changing temperature, and more influenced by particulate protein quantity, than were free-living bacteria (Table 2). Temperature and particulate protein together explained about $44 \%$ of the variance in thymidine incorporation per attached cell.

Attached bacteria also appeared to be more affected by the quality of particulate substrates, as shown by their response to changes in the ratio of phaeophytin to chlorophyll (Table 2).

In summary, although in most of the Bay attached bacteria make up a low fraction of the total bacteria assemblage (typically $\leq 10 \%$ ), they appear to be significant agents of phytoplankton decomposition and possibly consumers of oxygen. Moreover, the activities of particle-associated bacteria may be controlled by substrate accessibility to a greater extent than are those of free-living bacteria. Like other estuaries, Cheaspeake Bay is a system characterized by naturally and artificially enhanced levels of particles and attached bacteria. However, the strong, predictable gradients of physical, chemical and biological properties in the Bay provide a natural laboratory in which the effects of these factors on attached bacterial ecology and physiology can be studied with some success.

\section{LITERATURE CITED}

Abacus Concepts (1989). SuperANOVA, Version 1.11 Abacus Concepts, Berkeley, CA

Baines, S., Pace, M. (1991). The production of dissolved organic matter by phytoplankton and its importance to bacteria: patterns across marine and freshwater systems. Limnol. Oceanogr. 36: 1078-1090

Bolter, M. (1982). Submodels of a brackish water environment. I. Temperature and microbial activity. Ecol. Modelling 17: 311-318

Clarke, K. R., Joint, I. R. (1986). Methodology for estimating numbers of free-living and attached bacteria in estuarine water. Appl environ. Microbiol. 51: 1110-1120

Coffin, R., Sharp, J. (1987). Microbial trophodynamics in the Delaware Estuary. Mar. Ecol. Prog. Ser. 41: 253-266

Cole, J. J., Pace, M. L., Findlay, S. (1988). Bacterial production in fresh and saltwater ecosystems: a cross-system overview. Mar. Ecol. Prog. Ser. 43: 1-10

Ducklow, H. W. (1992). Factors regulating bottom-up control of bacterial biomass in open ocean plankton communities. Archiv. Hydrobiol. Beih. Ergeb. Limnol. 37: 207-217

Ducklow, H. W. Carlson, C. A. (1992). Oceanic bacterial productivity. Adv. microb. Ecol. 12: 113-181

Ducklow, H. W., Shiah, F.-K. (1993). Bacterial production in estuaries. Aquatic microbiology: an ecological approach.
Blackwell Scientific Publications, Cambridge, MA, p $261-288$

Findlay, S., Pace, M., Lints, D., Cole, J., Caraco, N., Peierls, B (1991). Weak coupling of bacterial and algal production in a heterotrophic ecosystem: the Hudson River estuary. Limnol Oceanogr. 36: 268-278

Fisher, T R., Harding, L. W. Jr, Stanley, D. W., Ward, L. G. (1988). Phytoplankton, nutrients and turbidity in the Chesapeake, Delaware and Hudson estuaries. Estuar. coast. Shelf Sci. 27: 61-93

Fuhrman, J., Azam, F. (1980). Bacterioplankton secondary production estimates for coastal waters of British Columbia, Antarctica, and California. Appl. environ. Microbiol. 39: $1085-1095$

Fuhrman, J., Azam, F. (1982). Thymidine incorporation as a measurement of heterotrophic bacterioplankton production in marine surface waters: evaluation and field results. Mar. Biol. 66: 109-120

Griffith, P. C., Fletcher, M. (1990). A model system derived from planktonic algae for investigating the activity of particle-associated bacteria. J. microbiol. Meth. 12: 65-74

Griffith, P. C., Fletcher, M. (1991). Hydrolysis of protein and model dipeptide substrates by attached and nonattached marine Pseudomonas sp. strain NCIMB 2021. Appl. environ. Microbiol. 57: 2186-2191

Hobbie, J., Daley, R., Jasper, S. (1977). Use of Nuclepore filters for counting bacteria by fluorescence microscopy. Appl. environ. Microbiol. 33: 1225-1228

Hoppe, H. G. (1991). Microbial extracellular enzyme activity: a new key parameter in aquatic ecology. In: Chróst, R. J. (ed.) Microbial enzymes in aquatic environments. Springer-Verlag, New York, p. 60-122

lriberri, J., Undurraga, A., Muela, A., Egea, L. (1985). Heterotrophic bacterial activity in coastal waters: functional relationship of temperature and phytoplankton population. Ecol. Modelling 28: 113-120

Jonas, R. (1992). Microbial processes, organic matter, and oxygen demand in the water column. Oxygen dynamics in the Chesapeake Bay. Maryland Sea Grant, College Park, p. $113-148$

Kefford, B., Kjelleberg, S., Marshall, K. C. (1982). Bäcterial scavenging: utilization of fatty acids localized at a solid/liquid interface. Arch. Microbiol. 133: 257-260

Kirchman, D., Mitchell, R. (1982). Contribution of particlebound bacteria to microheterotrophic activity in five coastal ponds and two marshes. Appl. environ. Microbiol. 43: $200-209$

Lovell, C., Konopka, A. (1985). The effects of temperature on bacterial production in a dimictic eutrophic lake. FEMS Microbiol. Ecol. 31: 135-140

Malone, T., Ducklow, H. W. (1990). Microbial biomass in the coastal plume of Chesapeake Bay: phytoplanktonbacterioplankton relationships. Limnol. Oceanogr 35: $296-312$

Malone, T., Kemp, W., Ducklow, H. W., Boynton, W., Tuttle, J., Jonas, R. (1986). Lateral variation in the production and fate of phytoplankton in a partially stratified estuary. Mar. Ecol. Prog. Ser. 32: 149-160

Malone, T. C., Crocker, L. H., Pike, S. E., Wendler, B. W. (1988). Influences of river flow on the dynamics of phytoplankton production in a partially stratified estuary. Mar. Ecol. Prog. Ser. 48: 235-249

Painchaud, J., Lefaivre, D., Therriault, J.-C. (1987). Box model analysis of bacterial fluxes in the St. Lawrence Estuary. Mar. Ecol. Prog. Ser. 41: 241-252

Pomeroy, L., Deibel, D. (1986). Temperature regulation of bacterial activity during the spring bloom in Newfound- 
land coastal waters. Science 233: 359-361

Pomeroy, L., Wiebe, W., Deibel, D., Thompson, R., Rowe, G., Pakulski, J. (1991). Bacterial responses to temperature and substrate concentration during the Newfoundland spring bloom. Mar. Ecol. Prog. Ser. 75: 143-159

Sokal, R., Rohlf, F. (1969). Introduction to biostatistics. W. H. Freeman, San Francisco

This article was presented by S. Y. Newell (Senior Editorial Advisor), Sapelo Island, Georgia, USA
White, P., Kalff, J., Rasmussen, J., Gasol, J. (1991). The effects of temperature and algal biomass on bacterial production and specific growth rate in freshwater and marine habitats. Microb. Ecol. 21: 99-118

Wiebe, W., Sheldon, W., Pomeroy, L. (1992). Bacterial growth in the cold: evidence for an enhanced substrate requirement. Appl. environ. Microbiol. 58: 359-364

Manuscript first received: September 1, 1993 Revised version accepted: February 17, 1994 